\title{
ANALISIS KESALAHAN PESERTA DIDIK DALAM MENYELESAIKAN SOAL CERITA SISTEM PERSAMAAN LINEAR DUA VARIABEL
}

\section{STUDENT MISTAKE ANALYSIS IN SOLVING PROBABILITY STORY OF LINEAR EQUATION SYSTEM TWO VARIABLES}

\author{
Luluk Ilmiyah $^{1}$, Sujoko Purnomo ${ }^{2}$, Sizillia Noranda Mayangsari ${ }^{3}$ \\ ${ }^{1,2,3}$ Wisnuwardhana \\ ${ }^{1,2,3}$ Malang \\ Email: luluk.ilmiyah11@gmail.com¹, sujoko4571@ gmail.com², sizillia@wisnuwardhana.ac.id ${ }^{3}$
}

\begin{abstract}
Abstrak
Tujuan penulisan ini adalah untuk mendeskripsikan kesalahan-kesalahan peserta didik dalam menyelesaikan soal cerita SPLDV. Identifikasi latar belakang masalah dari penelitian ini adalah masih banyak peserta didik yang mengalami kesalahan dalam menyelesaikan soal cerita tentang Sistem Persamaan Linier Dua Variabel. Penelitian ini merupakan penelitian deskriptif dengan pendekatan kualitatif. Subjek dalam penelitian ini adalah peserta didik kelas VIII SMP Negeri 1 PAKIS, Kabupaten Malang yang berjumlah 31 peserta didik. Analisis dilakukan dengan menggunakan tahapan Newman. pengumpulan data dilakukan menggunakan instrumen tes dan non tes. Hasil penelitian menunjukkan bahwa sebagian besar peserta didik masih melakukan kesalahan dalam menyelesaikan soal cerita SPLDV. Dalam penelitian ini, ditemukan jumlah peserta didik yang malakukan kesalahan dalam menyelesaikan soal cerita berdasarkan tipe kesalahan tahapan Newman, yaitu 1). 4 peserta didik salah pada tahap Reading (membaca), 2). 6 peserta didik salah pada tahap Comprehension (memahami), 3 ). 6 peserta didik salah pada tahap transformation (transformasi), 4). 7 peserta didik salah pada tahap Process Skill (keterampilan proses), 5). 4 peserta didik salah pada tahap Encoding (pengkodean).
\end{abstract}

Kata Kunci: Kesalahan, Newman, SPLDV.

\begin{abstract}
The purpose of this paper is to describe the errors of students in solving the problem of SPLDV story Identify the background of the problem of this research is still a lot of students who have errors in solving the story of the System of Two Variable Linear Equations. This research is a descriptive research with qualitative approach. Subjects in this study were students of class VIII SMP Negeri 1 PAKIS, Malang regency which amounted to 31 students. The analysis is done by using the Newman stages. data collection was conducted using test and non test instruments. The results show that most students still make mistakes in solving the SPLDV story problem. In this study, found the number of students who make mistakes in solving the story problem based on the type of error Newman stages, namely 1). 4 students are wrong at the Reading stage (reading), 2). 6 students are wrong at the Comprehension stage (understand), 3). 6 students are wrong at the transformation stage, 4). 7 students are wrong at Process Skill stage (process skill), 5). 4 students are wrong on the Encoding (encoding) stage.
\end{abstract}

Keywords: Error, Newman, SPLDV

\section{Pendahuluan}

Matematika merupakan salah satu mata pelajaran yang diajarkan pada setiap jenjang pendidikan. Banyak peserta didik beranggapan bahwa pelajaran matematika membosankan dan tidak menarik, hal ini disebabkan karena pelajaran matematika dirasakan sukar dan rumit. Seperti yang diungkapkan oleh Abdurrahman (2012) banyak 
yang memandang matematika sebagai bidang studi yang paling sulit. Hal ini menjadi stigma yang berkembang pada diri peserta didik secara berkelanjutan. Dalam pembelajaran matematika, peserta didik seringkali mengalami kesalahan dalam menyelesaikan soal matematika. Sehingga dapat mempengaruhi hasil belajar peserta didik.

Idris (2011) mengungkapkan bahwa kesalahan merupakan sesuatu yang mendasar dan positif dalam proses belajar. Namun, kenyataannya, kesalahan juga dapat menurunkan rasa percaya diri peserta didik dalam menyelesaikan masalah sehingga dapat berakibat pada menurunnya kemampuan peserta didik. Melakukan kesalahan dalam menyelesaikan soal matematika merupakan suatu yang wajar. Akan tetapi jika peserta didik sering melalukan kesalahan dalam mengerjakan soal matematika, hal tersebut akan menimbulkan masalah. Mengingat bahwa matematika adalah mata pelajaran yang materinya saling terkait dan berhubungan dengan materi-materi berikutnya.

Sebagaimana yang diungkapkan oleh Radatz dalam Blanco \& Garrote (2007) kesalahan peserta didik dalam menyelesaikan masalah matematika merupakan hasil atau produk dari pengalaman pembelajaran matematika sebelumnya. Dalam melaksanakan pembelajaran tentunya guru melaksanakan strategi yang berbeda (In'am, 2012). Hal ini karena kesadaran guru bahwa kemampuan setiap peserta didik dalam menangkap materi berbeda. Cara guru dalam menangani kesalahan peserta didik juga berpengaruh dalam mengatasi kesalahan yang dilakukan peserta didik yang dapat dipengaruhi oleh pengetahuan dana kepercayaan guru dalam mengajarkan matematika (Bray, 2011). Cara guru dalam mengatasi kesalahan yang muncul dari peserta didik dapat diorganisasikan dalam pembelajaran yang memunculkan kolaborasi dari pengetahuan dan kepercayaan guru dalam mengajarkan suatu konsep matematika.

Adapun Solichan (Damayanti, 2017) berpendapat bahwa analisis kesalahan merupakan suatu upaya penyelidikan untuk melihat, mengamati, mengetahui, menemukan, memahami, menelaah, mengklasifikasi, dan mendalami bentuk penyimpangan terhadap hal yang dianggap benar atau penyimpangan terhadap sesuatu yang telah ditetapkan/disepakati sebelumnya

Peraturan Mendiknas No. 23 tahun 2006 tentang standar kelulusan peserta didik salah satunya disebutkan bahwa untuk mempelajari matematika di SMP standar yang diharapkan adalah peserta didik menunjukkan kemampuan berpikir logis, kritis, kreatif dan inovatif, menunjukkan kemampuan belajar secara mandiri sesuai potensi yang dimilikinya dan menunjukkan kemampuan menganalisis dan memecahkan masalah dalam kehidupan sehari-hari. Selama proses pembelajaran matematika peserta didik sering sekali dihadapkan pada soal yang tidak dengan segera dapat diselesaikan artinya peserta didik harus berpikir dan bernalar terlebih dahulu, mencoba, menaksis, memodelkan dan menggunakan rumus-rumus sederhana dan kemudin baru membuktikannya, karena itu peserta didik perlu memiliki keterampilan berpikir.

Salah satu materi yang harus dipelajari oleh peserta didik sekolah menengah pertama adalah Sistem Persamaan Linear Dua Variable (SPLDV). Dalam SPLDV soal biasa berbentuk cerita yang kontekstual, untuk menyelesaikan persoalan tersebut perlu adanya tahap memodelkan secara matematis atau merepresentasikan, baru selanjutnya soal tersebut dapat diselesaikan. Banyak peserta didik yang masih kesulitan mempelajari materi SPLDV. Hal tersebut diungkapkan oleh hidayah (2016) berdasarkan hasil penelitiannya tentang analisis kesalahan dalam menyelesaikan soal cerita SPLDV berdasarkan langkah penyelesaian Polya menyatakan bahwa jenis-jenis 
kesalahan yang dilakukan peserta didik dan faktor penyebab terjadinya kesalahan yang dilakukan peserta didik antara lain (1) kesalahan memahami soal (2) kesalahan menyusun rencana (3) kesalahan melaksanakan rencana dan (3) kesalahan memeriksa kembali solusi yang diperoleh.

Kesalahan yang dilakukan oleh setiap peserta didik bisa saja berbeda. Kesalahan yang dilakukan pada langkah pertama akan mengakibatkan kesalahan pada langkahlangkah berikutnya, karena soal matematika secara umum diselesaikan secara berurutan atau mempunyai tahapan yang sistematis.

Budiyono (2008) mengungkapkan bahwa langkah ketiga akan terjawab dengan benar jika peserta didik tidak melakukan kesalahan pada langkah kedua. Demikian juga, langkah kedua akan terjawab dengan benar jika peserta didik tidak melakukan kesalahan pada langkah pertama.

Berdasarkan hasil penelitian yang dilakukan oleh San Pedro (2014) menemukan bahwa peserta didik yang ceroboh dan mengalami kesalahan seringkali adalah peserta didik yang tampak antusias dalam belajar. Sebaliknya, peserta didik yang malas dan bosan selama pembelajaran mengalami kesalahan akibat kecorobohan lebih sedikit. Newman (White, 2005) mengklasifikasikan kesalahan peserta didik dalam menyelesaikan soal matematika sebagai berikut.

a. Reading (membaca)

Tahap dimana peserta didik mampu membaca kata kunci atau simbol pada soal sehingga peserta didik tidak dapat melangkah lebih lanjut pada pola penyelesaian masalah yang tepat, atau peserta didik tidak dapat membaca pertanyaan dan menulikan informasi-informasi apa saja yang terdapat pada soal.

Indikator Kesalahan pada tahapan ini adalah Tidak dapat membaca katakata yang diajukan dalam soal.

b. Comprehension (memahami)

Tahap dimana peserta didik mampu membaca semua kata dalam soal akan tetapi tidak menguasai secara keseluruhan pengertian kata-kata tersebut, sehingga peserta didik tidak dapat melangkah lebh lanjut pada pola penyelesaian masalah yang tepat atau peserta didik tidak mengetahui apa yang menjadi pertanyaan pada soal

Indikator kesalahan pada tahap ini adalah : 1) Salah menuliskan apa yang diketahui dari soal. 2) Menuliskan apa yang diketahui dan ditanyakan sama persis dengan soal tetapi tidak melanjutkan proses. 3) Menuliskan apa yang diketahui dan ditanyakan tetapi tidak bermakna (tidak jelas). 4) Menuliskan apa yang diketahui dan ditanyakan tapi ada info penting yang terlewat.

c. Transformation (transformasi)

Tahap dimana jika peserta didik mampu memahami apa yang diinginkan soal tetapi tidak mampu mengidentifikasi operasi dan prosedur yang dibutuhkan untuk menyelesaikan masalah.

Indikator kesalahan pada tahap ini adalah : 1) Tidak mengubah informasi pada soal ke dalam bentuk persamaan linier. 2) Mengubah informasi pada soal ke dalam bentuk persamaan linier tapi tidak tepat. 3) Sudah mengubah informasi pada soal, tetapi tidak menuliskan keterangan secara lengkap (dalam puluhan, ratusan, atau ribuan). 
d. Process skill (keterampilan proses)

Tahap dimana peserta didik telah mengidentiikasi operasi atau prosedur yang tepat, akan tetapi tidak mengetahui prosedur yang diperlukan untuk menyelesaikan operasi tersebut secara akurat.

Indikator kesalahan pada tahap ini adalah : 1) Kesalahan dalam komputasi. 2) Tidak dapat melanjutkan prosedur penyelesaian (macet). 3) Melanjutkan proses komputasi tetapi tidak tepat karena ada salah konsep aljabar. 4) Ceroboh dalam proses perhitungan

e. Encoding (pengkodean)

Tahap dimana peserta didik telah menemukan solusi atas permasalahan, akan tetapi salah menentukan jawaban akhir atau tidak menyajikan jawaban yang tepat.

Indikator kesalahan pada tahap ini adalah : 1) Menuliskan notasi (tanda negatif, simbol, tanda sama dengan, dll) secara tidak tepat. 2) Tidak menuliskan variabel/satuan. 3) Salah penggunaan satuan.

Tujuan penelitian ini adalah untuk mengetahui dan mendeskripsikan kesalahan-kesalahan yang dialami peserta didik kelas VIII SMP Negeri 1 PAKIS dalam menyelesaikan soal sistem persamaan linear dua variabel (SPLDV) berdasarkan klasifikasi kesalahan dari Newman

\section{Metode Penelitian}

Dalam penelitian ini menggunakan pendekatan kualitatif, yaitu pendekatan dalam mengolah data mulai dari mereduksi, menyajikan, memverifikasi, dan menyimpulkan data, dengan tidak menggunakan perhitungan-perhitungan secara matematis dan statistik, melainkan lebih menekankan pada kajian interpretatif.

Sumber data dalam penelitian ini adalah peserta didik kelas VIII SMP Negeri 1 PAKIS. sedangkan subjek penelitian adalah peserta didik kelas VIII-A SMP Negeri 1 PAKIS. Instrumen tes pada penelitian ini dilaksanakan di SMP Negeri 1 PAKIS yang menjadi sampel adalah kelas VIII-A. Penelitian terhadap instrumen tes ini dilaksanakan pada saat proses peneliti melaksanakan Praktek Pengalaman Lapangan (PPL) di SMPN 1 PAKIS tersebut

Proses analisis data dimulai dengan menelaah seluruh data yang tersedia dari berbagai sumber yaitu dari wawancara, pengamatan, yang sudah ditulis dalam catatan lapangan, dokumen pribadi, dokumen resmi, gambar, foto dan sebagainya. Berdasarkan hal tersebut maka analisis data dalam penelitian ini dilakukan selama dan setelah pengumpulan data yang terkumpul.

Sedangkan tahap-tahap dalam penelitian tindakan ini mencangkup tahap perencanaan dan tahap pelaksanaan kegiatan penelitian. Rincian kegiatan dari tahaptahap tersebut adalah sebagai berikut :

1. Tahap perencanaan, meliputi :

a. Refleksi awal, pada tahap ini dilakukan kegiatan yang meliputi observasi awal ke sekolah SMP Negeri 1 PAKIS, wawancara dengan guru bidang studi matematika yang mengajar di kelas VIII-A SMP Negeri 1 PAKIS tentang permasalahan-permasalahan yang dihadapi peserta didik dalam mempelajari matematika, membuat soal tes, memilih subyek penelitian. 
b. Menetapkan dan merumuskan rancangan tindakan, pada tahap ini, kegiatan yang dilakukan adalah menentukan tujuan pembelajaran, menyusun kegiatan pembelajaran SPLDV.

2. Tahap Pelaksanaan Tindakan

Pelaksanaan tindakan dalam penelitian ini dilakukan mengikuti alur tindakan yang meliputi kegiatan :

a. Rencana penelitian, kegiatan yang dilakukan pada tahap ini adalah sebagai berikut : Menyusun rencana pembelajaran, menyiapkan materi pelajaran yang akan disajikan, menyiapkan format observasi, menyiapkan perangkat tes akhir terhadap hasil belajar.

b. Pelaksanaan tindakan, kegiatan yang dilakukan pada tahap ini adalah melakukan tindakan pembelajaran sesuai dengan rencana yang telah disusun dalam rencana pembelajaran

c. Observasi, kegiatan yang akan dilakukan pada ini adalah mendokumentasikan segala sesuatu yang berkaitan dengan pemberian tindakan.

d. Refleksi, kegiatan yang akan dilaksanakan pada tahap ini adalah menganalisa hasil pekerjaan peserta didik, menganalisa hasil wawancara, menganalisis lembar observasi peserta didik menganalisis lembar observasi peneliti.

Hasil analisis tersebut, peneliti melakukan refleksi yang akan digunakan sebagai bahan pertimbangan apakah kriteria yang telah ditetapkan tercapai atau belum. Ketika peserta didik belum mencapai kriteria ketutantasan atau mengalami kesalahan dalam menyelesaikan soal cerita pada materi SPLDV.

\section{Hasil dan Pembahasan}

\subsection{Hasil}

Berdasarkan hasil pekerjaan peserta didik maka hasil analisis tipe kesalahan berdasarkan teori Newman dapat dilihat pada Tabel 1 berikut.

Tabel 1. Identifikasi kesalahan peserta didik

\begin{tabular}{clc}
\hline \multirow{2}{*}{$\begin{array}{c}\text { Tipe } \\
\text { Kesalahan }\end{array}$} & \multicolumn{1}{c}{ Indikator Kesalahan } & $\begin{array}{c}\text { Banyak } \\
\text { peserta didik } \\
\text { yang } \\
\text { melakukan } \\
\text { kesalahan }\end{array}$ \\
\hline Membaca & $\begin{array}{l}\text { Tidak dapat membaca kata-kata yang diajukan } \\
\text { dalam soal }\end{array}$ & 4 \\
\hline Memahami & Salah menuliskan apa yang diketahui dari soal. & 2 \\
\cline { 2 - 3 } & $\begin{array}{l}\text { Menuliskan apa yang diketahui dan ditanyakan } \\
\text { sama persis dengan soal tetapi tidak melanjutkan } \\
\text { proses. }\end{array}$ & 2 \\
\cline { 2 - 3 } & $\begin{array}{l}\text { Menuliskan apa yang diketahui dan ditanyakan } \\
\text { tetapi tidak bermakna (tidak jelas). }\end{array}$ & 1 \\
\cline { 2 - 3 } & $\begin{array}{l}\text { Menuliskan apa yang diketahui dan ditanyakan } \\
\text { tapi ada info penting yang terlewat. }\end{array}$ & 1 \\
\hline
\end{tabular}




\begin{tabular}{lll}
\hline Transformasi & $\begin{array}{l}\text { Tidak mengubah informasi pada soal ke dalam } \\
\text { bentuk persamaan linier. }\end{array}$ & 3 \\
\cline { 2 - 3 } & $\begin{array}{l}\text { Mengubah informasi pada soal ke dalam bentuk } \\
\text { persamaan linier tapi tidak tepat. }\end{array}$ & 2 \\
\hline & $\begin{array}{l}\text { Sudah mengubah informasi pada soal, tetapi } \\
\text { tidak menuliskan keterangan secara lengkap } \\
\text { (dalam puluhan, ratusan, atau ribuan). }\end{array}$ & 1 \\
\hline Keterampilan & Kesalahan dalam komputasi. & 1 \\
& $\begin{array}{l}\text { Tidak dapat melanjutkan prosedur penyelesaian } \\
\text { (macet). }\end{array}$ & 4 \\
\cline { 2 - 3 } & $\begin{array}{l}\text { Melanjutkan proses komputasi tetapi tidak tepat } \\
\text { karena ada salah konsep aljabar. } \\
\text { Ceroboh dalam proses perhitungan }\end{array}$ & 1 \\
\hline Pengkodean & $\begin{array}{l}\text { Kesalahan dalam komputasi. } \\
\text { Tidak dapat melanjutkan prosedur penyelesaian } \\
\text { (macet). } \\
\text { Melanjutkan proses komputasi tetapi tidak tepat } \\
\text { karena ada salah konsep aljabar. } \\
\text { Ceroboh dalam proses perhitungan }\end{array}$ & 1 \\
\hline
\end{tabular}

\subsection{Pembahasan}

Berdasarkan hasil analisis kesalahan peserta didik dalam menyelesaikan soal SPLDV, berikut data kesalahan peserta didik dalam menyelesaikan soal cerita SPLDV.

1. Reading (membaca)

Tahap dimana peserta didik mampu membaca kata kunci atau simbol pada soal sehingga peserta didik tidak dapat melangkah lebih lanjut pada pola penyelesaian masalah yang tepat, atau peserta didik tidak dapat membaca pertanyaan dan menulikan informasi-informasi apa saja yang terdapat pada soal.

Pada tahap ini ditemukan 4 peserta didik melakukan kesalahan, atau sebanyak $12,9 \%$ jika disajikan dalam betuk persentase. Indikator Kesalahan pada tahapan ini adalah Tidak dapat membaca kata-kata yang diajukan dalam soal. Berikut contoh kesalahan peserta didik pada tahap Reading (membaca). 


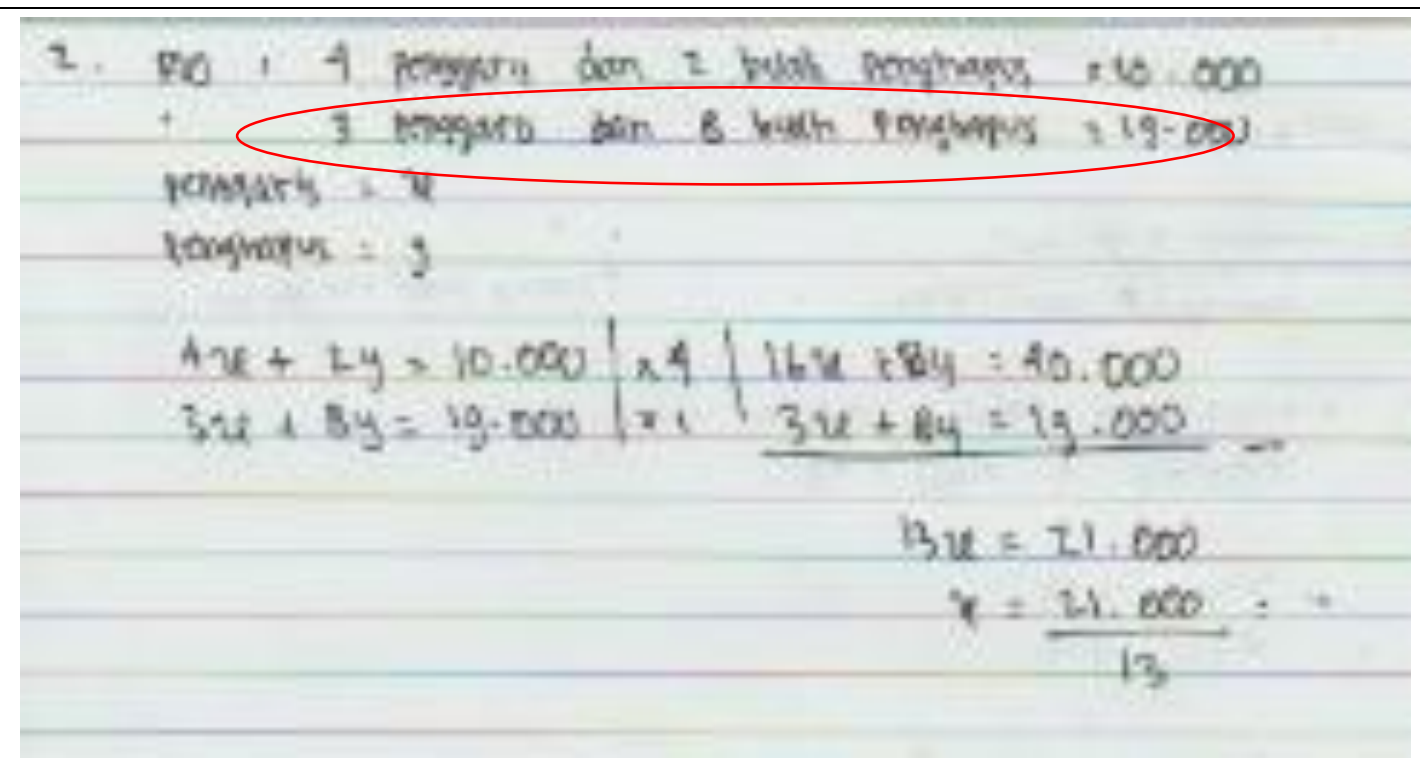

Gambar 1. Kesalahan peserta didik pada tahap reading (membaca)

2. Comprehension (memahami)

Tahap dimana peserta didik mampu membaca semua kata dalam soal akan tetapi tidak menguasai secara keseluruhan pengertian kata-kata tersebut, sehingga peserta didik tidak dapat melangkah lebih lanjut pada pola penyelesaian masalah yang tepat atau peserta didik tidak mengetahui apa yang menjadi pertanyaan pada soal

Pada tahap ini, ditemukan 6 anak melakukan kesalahan, atau 19,4\% dari 31 Peserta didik. Jumlah peserta didik yang melakukan kesalahan pada setiap indikator kesalahan di tahap ini adalah : 1). dua peserta didik salah menuliskan apa yang diketahui dari soal. 2). dua peserta didik menuliskan apa yang diketahui dan ditanyakan sama persis dengan soal tetapi tidak melanjutkan proses. 3). satu peserta didik menuliskan apa yang diketahui dan ditanyakan tetapi tidak bermakna (tidak jelas). 4) satu peserta didik menuliskan apa yang diketahui dan ditanyakan tapi ada info penting yang terlewat. Berikut contoh kesalahan peserta didik pada tahap ini. 


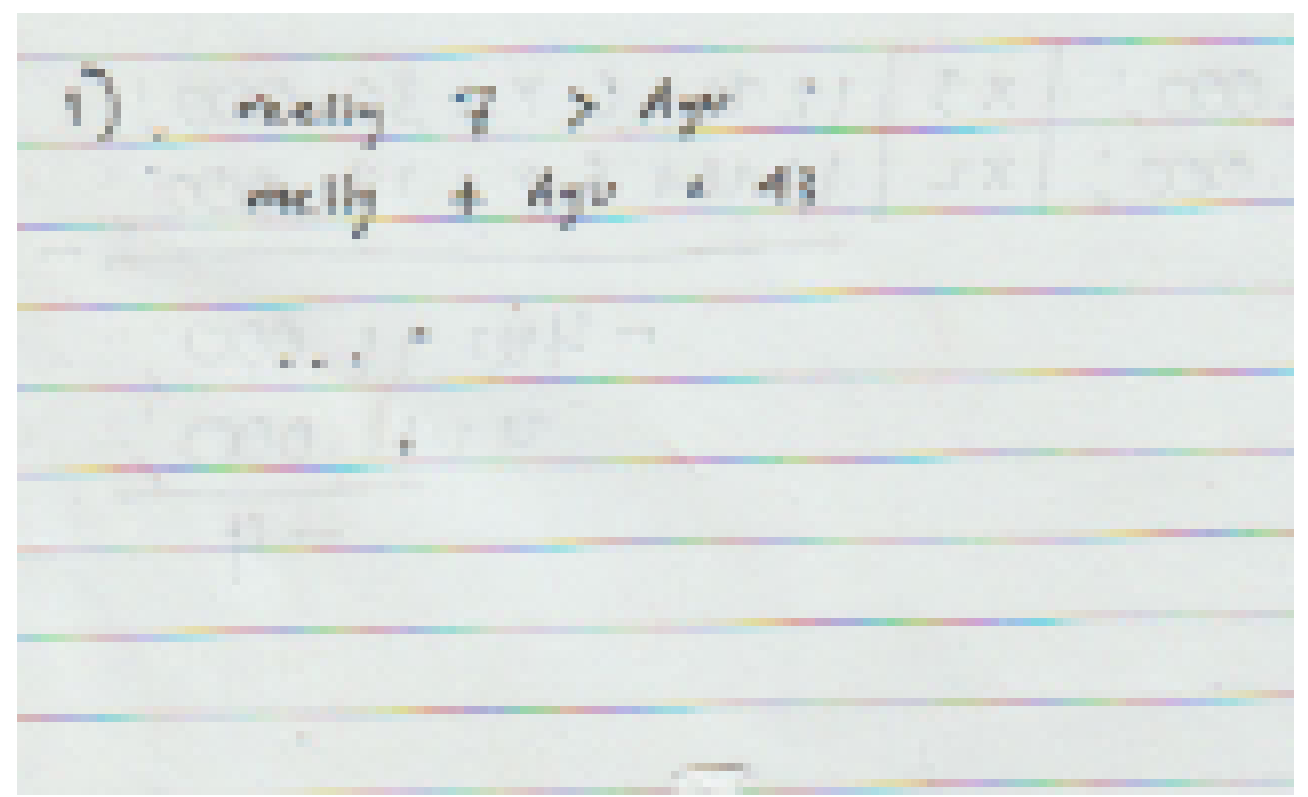

Gambar 2. Contoh kesalahan peserta didik pada tahap comprehension

3. Transformation (transformasi)

Tahap dimana jika peserta didik mampu memahami apa yang diinginkan soal tetapi tidak mampu mengidentifikasi operasi dan prosedur yang dibutuhkan untuk menyelesaikan masalah.

Pada tahap ini ditemukan 6 peserta didik yang melakukan kesalahan, atau sebesar 6,5 \% dari 31 peserta didik. Jumlah peserta didik yang melakukan kesalahan pada setiap indikator kesalahan di tahap ini adalah : 1). tiga peserta didik tidak mengubah informasi pada soal ke dalam bentuk persamaan linier. 2). dua peserta didik mengubah informasi pada soal ke dalam bentuk persamaan linier tapi tidak tepat. 3). satu peserta didik sudah mengubah informasi pada soal, tetapi tidak menuliskan keterangan secara lengkap (dalam puluhan, ratusan, atau ribuan.

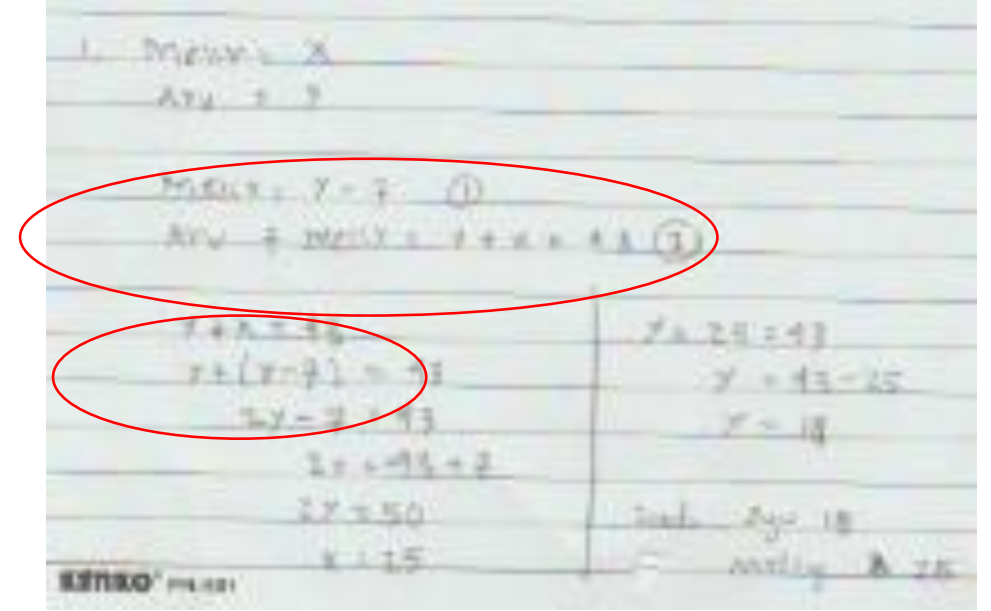

Gambar 3. Contoh kesalahan peserta didik pada tahap transformation

4. Process skill (keterampilan proses)

Tahap dimana peserta didik telah mengidentiikasi operasi atau prosedur yang tepat, akan tetapi tidak mengetahui prosedur yang diperlukan untuk menyelesaikan operasi tersebut secara akurat. 
Ditemukan sebanyak 7 peserta didik yang melakukan kesalahan pada tahap ini, atau 22,6 \% dari 31 peserta didik. Indikator kesalahan pada tahap ini adalah : 1). satu peserta didik melakukan kesalahan dalam komputasi. 2) empat peserta didik tidak dapat melanjutkan prosedur penyelesaian (macet). 3) satu peserta didik melanjutkan proses komputasi tetapi tidak tepat karena ada salah konsep aljabar. 4) satu peserta didik ceroboh dalam proses perhitungan

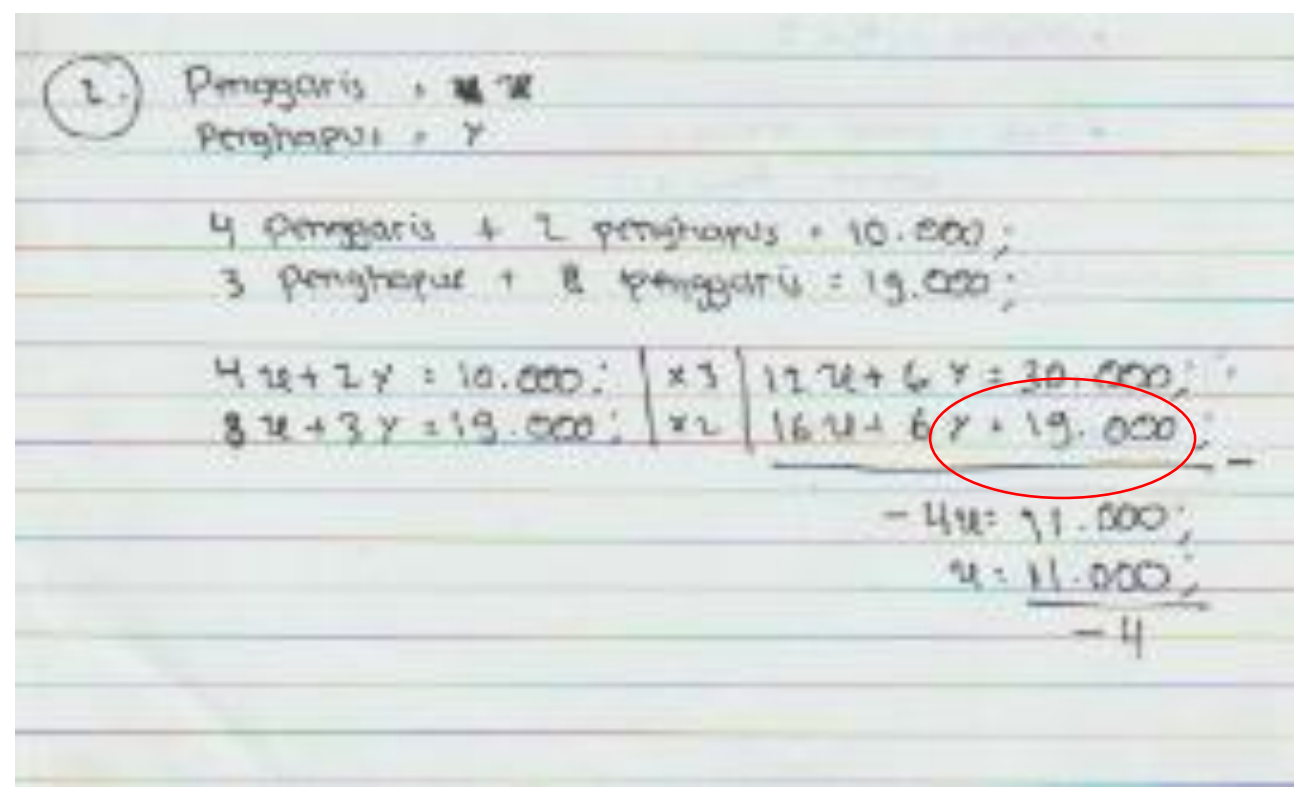

Gambar 4. Contoh kesalahan peserta didik pada tahap process skill

5. Encoding (pengkodean)

Tahap dimana peserta didik telah menemukan solusi atas permasalahan, akan tetapi salah menentukan jawaban akhir atau tidak menyajikan jawaban yang tepat.

Ditemukan sebanyak 4 peserta didik yang melakukan kesalahan pada tahap ini, atau 22,6 \% dari 31 peserta didik. Indikator kesalhan pada tahap ini adalah : 1) satu peserta didik salah menuliskan notasi (tanda negatif, simbol, tanda sama dengan, dll) secara tidak tepat. 2) satu peserta didik tidak menuliskan variabel/satuan. 3) satu peserta didik salah dalam penggunaan satuan. 


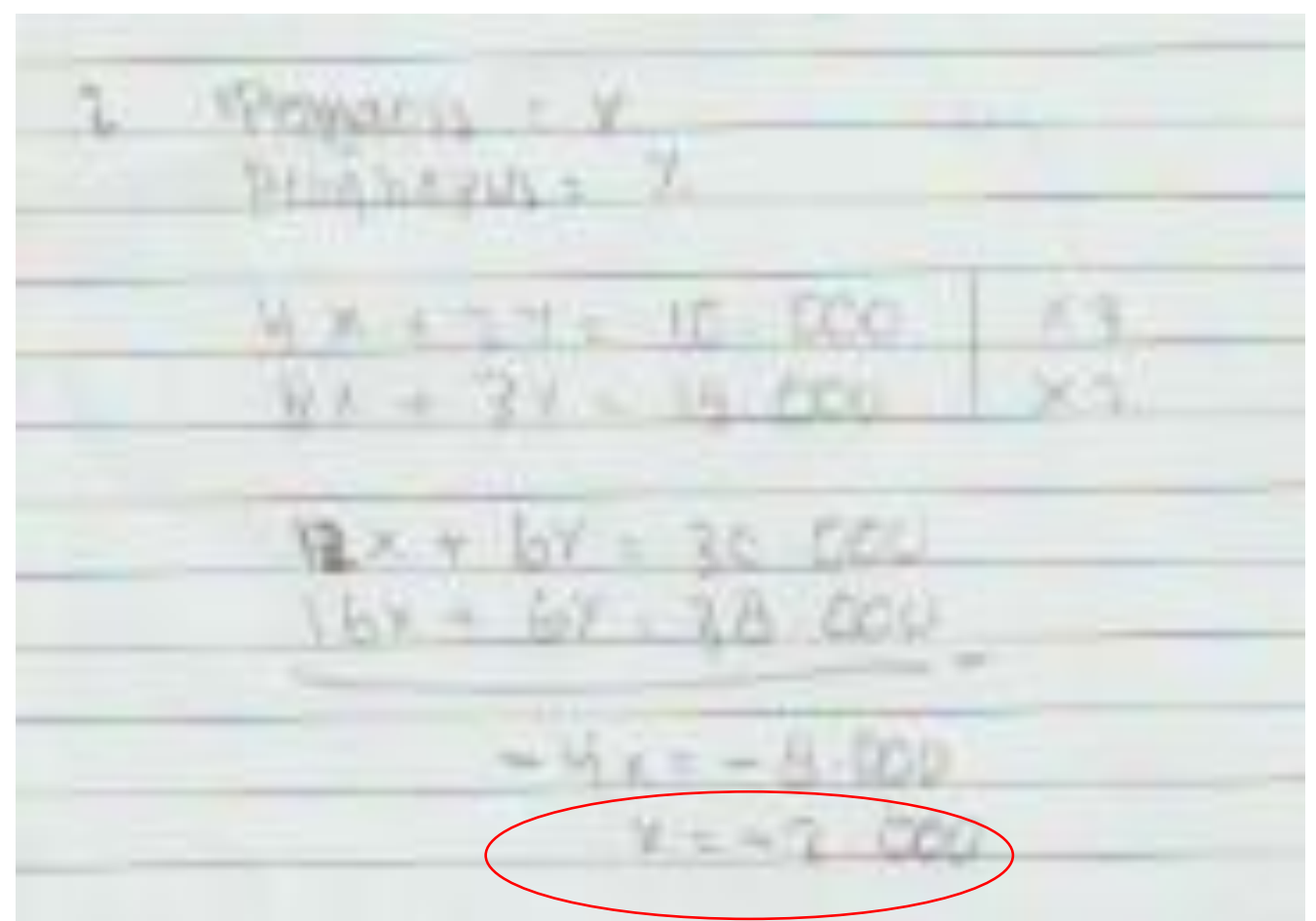

Gambar 5. Contoh kesalahan peserta didik pada tahap encoding

\section{Kesimpulan}

Berdasarkan hasil penelitian dapat disimpulkan bahwa jumlah peserta didik yang malakukan kesalahan dalam enyelesaikan soal cerita berdasarkan tipe kesalahan tahapan Newman, yaitu 1). empat peserta didik salah pada tahap reading (membaca), 2). empat peserta didik salah pada tahap comprehension (memahami), 3). enam peserta didik salah pada tahap transformation (transformasi), 4). tujuh peserta didik salah pada tahap process skill (keterampilan proses), 5). empat peserta didik salah pada tahap encoding (pengkodean).

\section{Daftar Pustaka}

Abdurrahman, M. (2012). "Anak berkesulitan belajar: teori, diagnosts, dan remedial”. Jakarta: Rineka Cipta.

Blanco and Garrote. 2007. "Difficulties in Learning Inequalities in Students of First Year of Pre-University Education in Spain”. EJMSTE. 221-229.

Bray, W. S. A. 2011. "Collective Case Study of The Influence of Teacher' Belief and Knowledge on ErrorHandling Practices During Class discussuon of Mathematics". Journal for Research in Mathematics education : 2-38.

Budiyono. 2008. "Kesalahan Mengerjakan Soal Cerita dalam Pembelajaran Matematika". Paidagogia: 1-8.

Hidayah, S. (2016) "Analisis Kesalahan Peserta didik dalam Menyelesaikan Soal Cerita SPLDV Berdasarkan Langkah Penyelesaian Polya". Prosiding Seminar Nasional Pendidikan Matematika 2016-Universitas Kanjuruhan Malang. Malang: 182-190. 
Idris, N. \& Narayanan, L. M. (20110. "Error Patterns in Addition and Subtraction of Fractions among Form Two Student”. Journal of Mathematics Education: 35-54.

In'am. (2012). "Perspectif Metakognitif Guru dalam Pembelajaran Matematika di Sekolah Dasar". Sekolah dasar Kajian Teori dan Praktik Pendidikan:133-144.

Damayanti, N. \& Mayangsari, S. (2017). 'Analisis kesalahan peserta didik dalam konsep operasi hitung pada pecahan”. Malang: JIE. 30-4

Rahayu, Putri. (2017). "Analisis Kesalahan dalam Menyelesaikan SPLDV". Yogyakarta: 2-3

San Pedro, M. O. Z., dkk. (2014). "Carelessness and Affectin an Intelligent Tutorung System for Mathematics". International Journal of Artificial Intelegence un education: $189-210$

White, A. L., (2005). "Active Mathematics in Classrooms: Finding Out Why Children Make Mistake and then doing Something to Help Them”. Square One: 15-19. 